\title{
"All that we see or seem / Is but a dream within a dream": Freud's The Uncanny and the Destruction of the Suburban Ideal in Jeffrey Eugenides's The Virgin Suicides
}

\section{Michael Madsen}

Aarhus University

\begin{abstract}
This essay discusses Jeffrey Eugenides's novel The Virgin Suicides (1993) in relation to Freud's theories of The Uncanny. The Uncanny arises in the sphere of the familiar and the unfamiliar. In the novel, there is something oddly familiar about the setting and the characters, but an unknown and unfamiliar element threatens the safe haven that is suburbia. The Lisbon girls are presented as symbols of the American Dream of a Promised Land, but end up representing an American Nightmare. Imprisoned and suffocated by their ever-decaying home, it becomes obvious that the only release in suburban life is death. For the boys narrating the novel, the Lisbon girls become an obsession. They become part of a collective dream of happiness, cleanness, and perfection. With dark humor Eugenides strips the glossy veneer of American suburbia, exposing a world of sickness and unhappiness.
\end{abstract}

Keywords: Sigmund Freud-suburbia-Jeffrey Eugenides-The Virgin Suicides - the uncanny-post-World War II America

Hearing the word "suburbia" immediately brings forth images in your mind: A car coming down a street "boasting of houses that provide comfort and privacy ..." with children playing on the sidewalk (Miller 1995, 403). The sun embracing a white picket fence as a dog barks in the distance. These images have become prevalent in the widely popular TV-series "Desperate Housewives" and movies such as American Beauty (1999) and Blue Velvet (1986). "Desperate Housewives" begins with the suicide of a suburban 
housewife, and the remainder of the first season focuses on the reasons for her untimely death. In the process, the skeletons come bursting out of the closet. The true lives of the other housewives portrayed in the show also prove that the image of perfect living they cling on to is anything but realistic. The same set-up is seen in American Beauty, also with death and trage$\mathrm{dy}$ as the result. Blue Velvet goes even deeper and shows a dark, sinister, and perverted world which shocks protagonist, Jeffrey (Kyle MacLachlan). The similarity between American Beauty, Blue Velvet, and "Desperate Housewives" is their portrayal of a world beyond the shiny veneer of "the burbs." Here one can experience the sickness that challenges the perfect image of carefree suburbia. This is also the reality of American suburbia in Jeffrey Eugenides's novel The Virgin Suicides (1993).

The post-World War II years in America saw the rise of suburbia and what would eventually lead to the ideal way of living in the States. While the origins of modern suburbia can be traced all the way back to late eighteenth-century London, it has become something that is defined as genuinely American (Fishman 4-5). Back at that time, living in the suburbs was about "[the] search for the perfect marriage of nature and culture ... desire to create a balanced life, the best of all worlds ...," and it became "a set of values and a way of life" (Silverstone 5, 3). Away from the noise, pollution, and crime of the big city, suburbia, on the surface, was a safe haven for families. The quest to separate the sphere of work with that of home could be achieved here. Also, "after two decades of depression and war, America was looking forward - to a fresh and prosperous future" (Martinson 58). It was time once again to rediscover and redefine the American Dream.

Tom Martinson quotes Scott Russell Sanders saying that the American Dream is "the dream of settling down, in peace and freedom and cooperation, in the promised land" (Martinson 23). Since suburbia offered such features it became just that: The Promised Land. Furthermore, the choice to move to the suburbs, according to Martinson, was "primarily about gaining personal space" (Martinson 54). Essentially, the intention behind it was similar to that of the settlement on the Frontier. Americans went out looking for personal space and freedom; the Frontier was discovered and eventually settled. Historian Frederick Jackson Turner announced in his thesis "The Significance of the Frontier in American History" (1893) that the Frontier was closed. He highlighted that "the experiences of isolation and the availability of free land had shaped American democracy and institutions" (Duncan 19). In the final pages of his book, Martinson concludes: "The 
timeless dream that unites Americans ... is simply having a place of their own-home" (Martinson 242).

In the suburbs described by Jeffrey Eugenides something has happened to this Promised Land where the American Dream was meant to exceed to new heights. The home that all Americans strive to have is no longer a safe haven of comfort and joy, but has turned into a prison where the inhabitants are living the American Nightmare. We are presented with a world where the shiny, perfect veneer of American suburban life is stripped away, revealing a dark reality beneath. The stability, order, and ideal way of living that the suburbs promised is revealed as empty or non-existent. This is a world where release and discovery of true personal space only comes through death.

In The Virgin Suicides, the one thing that Demo Karafilis's grandmother "'could never understand about America was why everyone pretended to be happy all the time"" (Eugenides 175). After experiencing the world described in this essay, it becomes apparent that, perhaps, it was about pretending all this time. When discussing The Virgin Suicides we can turn to the famous lines by Edgar Allan Poe: "All that we see or seem / Is but a dream within a dream" (Poe 336). For the Lisbon girls, the American Dream has become the American Nightmare.

The somewhat unnerving situation in The Virgin Suicides is created because everything looks normal, and yet something is very different from what we know and recognize. This different element, however, can be very hard to point out or even explain. What we see is strangely familiar and unfamiliar. In order for us to understand what we are dealing with, let us turn to Freud's "The Uncanny"1 (1919) that deals with this space between the familiar and the unfamiliar.

Freud begins his characterization of this phenomenon by saying that "[the uncanny] is undoubtedly related to that which is frightening - to what arouses dread and horror; equally certainly, too, the word is not always used in a clearly definable sense, so that it tends to coincide with what excites fear in general" (Freud 219). As Freud highlights, the interesting thing about the uncanny, is that the word, much like the phenomenon itself, is hard to define or grasp. He goes on to give many examples of the word in different languages trying to come up with an exact definition which some- 
what fails. The best way to define it is by looking at its meaning in German: Unheimlich. This word is "obviously the opposite of 'heimlich' ['homely'], 'heimisch' ['native'] - the opposite of what is familiar ..." (Freud 220). About the uncanny, Helene Cixous states that it can be "a unit in the "family'... [that] is not really a member of the family" (Cixous 528). Laura J. Miller's essay "Family Togetherness and the Suburban Ideal" addresses this as she writes: "The suburban ideal was always and explicitly about guarding against the encroachment of nonfamily members" (Miller 398). As we will see, the sense that something "heimlich" has become "unheimlich" is very important when it comes to the destruction of the ideal in The Virgin Suicides. In her discussion of the uncanny and the familiar versus the unfamiliar, Helene Cixous notes: "It is the between that is tainted with strangeness" (Cixous 543). On the same subject, Maria M. Tatar writes: "Uncanny events have the power to evoke a sense of dread precisely because they are at once strange and familiar" (Tatar 169).

Freud also alludes to something interesting when dealing with the word "Heimlich," seeing that it can also mean something secret or something kept from sight and concealed. By adding the prefix "un-," the definition changes and everything "that ought to have remained secret and hidden but has come to light" is unheimlich (Freud 225). According to Tatar: "the prefix $u n$-does not, as is usually the case, negate the meaning of the adjective, but functions rather as a "token of repression"” (Tatar 169). Throughout the essay I will return to Freud and the uncanny.

Freud brings forth the idea of "heimlich" being something "homelike" and "'belonging to the house' ..." (Freud 225). Furthermore, one definition of the word "heimlich" in Freud's essay is: "Intimate, friendlily comfortable; the enjoyment of quiet content... arousing a sense of agreeable restfulness and security as in one within four walls of his house" (Freud 222). In her discussion of the uncanny, Tatar writes: "A house contains the familiar and congenial, but at the same time it screens what is familiar and congenial from view, making a mystery out of it ... What takes place within the four walls of a house remains a mystery to those shut from it" (Tatar 169). In The Virgin Suicides the boys who function as the narrative voice are observing the Lisbon house along with the reader, wondering what exactly goes on in there. Even later when the boys enter the house, the mystery within it remains.

The Lisbon girls are inside the house fading away, and, meanwhile, the house itself fades away and dies with the girls. The house becomes "one big 
coffin" (Eugenides 163). It is even the "growing shabbiness of the house" that attracts the reporters wanting to find out, like all of us, why Cecilia and the rest of the girls killed themselves (93). In Sofia Coppola's 1999 movie based on the novel, she fails to fully capitalize on the notion that the house is decaying. Aside from a number over the front door hanging upside-down, there is virtually nothing that can be considered as a real sign of decay or death. This is a very important aspect of the novel and furthers the sensation of death and decay connected to the girls and the family.

When the girls are locked up inside the house after the prom, and Mr. Lisbon is fired, "the house truly died. For as long as Mr. Lisbon had gone back and forth to school, he circulated a thin current of life through the house, bringing the girls treats ... When Mr. Lisbon stopped going out, however, he stopped bringing home sweets" (162-163). With the firing of Mr. Lisbon, the last contact with the outside world dies. Essentially, no more sweetness or happiness enters the house: "[Mr. Lisbon] looked at the Good Humor truck passing by, the jingle of the bell seemed to trigger a memory, he smiled, or winced - we couldn't tell which - and returned inside" (59). In the end, the house comes to symbolize the decay of the Lisbon girls and the rot of suburbia. The idea that something is being hidden in the house is clear in the novel and the movie. Earlier on, "the front door was always left open, because one of the girls was always running in or out" (22). After the prom, Mrs. Lisbon chooses to isolate the girls, and "a cloud always seemed to hover over the Lisbon's roof. There was no explanation, except the psychic one that the house became obscured, because Mrs. Lisbon willed it to be" (141).

Evidently, the girls end up as prisoners in their own home. Martinson argues that the choice to move to the suburbs was "primarily about gaining personal space" (Martinson 54). In the vision of suburbia presented to us in The Virgin Suicides, the personal space has turned into a prison slowly killing the people in it. About the girls in The Virgin Suicides, the boys say: "Inside their house they were prisoners; outside, lepers. And so they hid from the world, waiting for someone - for us - to save them" (199). "Desperate Housewives" and American Beauty present a similar situation. The big suburban house imprisons these people who have been led to believe that everything is possible and wonderful in suburbia. Their imprisonment threatens to suffocate them and the release is adultery or suicide. In "Desperate Housewives," the suburban road, Wisteria Lane, which sounds like something almost magical out of The Wizard of $\mathrm{Oz}$, becomes the road to imprisonment, unhappiness, and, finally, death. 
The way Eugenides presents suburban life in The Virgin Suicides is comparable to the movies and TV-shows also referred to in this essay: The dreamlike world of carefree living has turned into a nightmare - reality has set in. A question that arises when reading The Virgin Suicides is if these girls are actually real or just products of the boys' imagination. The boys certainly mirror themselves in the visions of the girls, but actually the same can be said about the girls. When the boys are about to rescue the girls and take them away, they see Lux through the window: "she looked up at the window. She lifted her chin so that we thought she'd seen us, but then she ran her hand through her hair. She was only examining her reflection. The light inside the house made us invisible outside, and we stood inches from the window but unseen, as though looking in at Lux from another plane of existence" (208). Here it becomes obvious that the surface between the two worlds can function both as a window and as a mirror.

The surface between the two worlds, which are ironically the same world, creates a distance, but at the same time this only brings the two worlds closer together. The boys see themselves in the girls and, as they find out, it also works the other way around: "they had been looking out at us as intensely as we had been looking in" (124). We thus have voyeurs on both sides looking at each other. In Blue Velvet Jeffrey is at one crucial point trapped in the closet of the erotic Dorothy (Isabella Rossellini) and is witness to the evil Frank (Dennis Hopper) beating her up. To Jeffrey, this is an insight into a dark and sinister world he has previously been unaware of. Even if he is shocked and horrified, he is drawn to it in the safety of the closet, essentially on the outside looking in. According to Tatar, the uncanny feeling sets in when "a world once safe and secure becomes hostile and treacherous. This new world is situated at the crossroads of heimlich and unheimlich, at the point where the two words converge in meaning to suggest the sinister and oppressive" (Tatar 182). Again, the strangeness occurs in this space between the two worlds that have become one and the same. Whether it is a window or a closet door, the surface between the two worlds is blurred as the in-between pulls the two together making them at once familiar and unfamiliar.

To make the already familiar even more familiar and harmless, Jeffrey Eugenides works extensively with humor, and, overall, the novel is very humorous in spite of its tragic theme. On the subject of repetition and doubles in Freud's "The Uncanny," Cixous writes: "How many repetitions are necessary before distress turns into comedy?" (Cixous 540). In the case of 
The Virgin Suicides, Eugenides uses repetition as a way to create comedic moments. As autopsies are being performed on the girls, an "assembly-line approach" is being used. Eugenides's depiction of the mass burial of the girls is a great example of grotesque humor: "Because of limited available space, the girls' graves did not lie side by side but widely separated, so that the funeral party had to make the rounds, going from grave to grave at the excruciatingly slow speed of cemetery traffic" (239). The situation is made even more ridiculous with the information that a cemetery workers' strike ends on the day of Mary's suicide: "The strike's length has caused mortuaries to fill up months ago, and the many bodies awaiting burial now came back from out of state, in refrigerated trucks, or by airplane, depending on the wealth of the deceased. On the Chrysler Freeway one truck got into an accident, flipping over, and the front page of the newspaper ran a photo showing metal caskets spilling from the truck like ingots" (238-39).

However, Eugenides reminds us of the horrific events that these parents have been through by stating: "tragedy had beaten them into mindless submission" (239). It is, of course, a horrible situation to imagine: Mr. and Mrs. Lisbon having to bury all of their children on the same day. But the humor of the entire situation as described by Eugenides definitely sugarcoats the image and the story overall. Even if it is a story of taboos such as suicides, (mass) burials, and, not to forget, general distress and the decay of suburbia, it makes you laugh and feel comfortable. This is of course the intention, because you can be caught in this prosaic state with your guards down and the feeling of comfort can quickly be turned into something uncomfortable.

Eugenides says that he tends "to make bizarre things normal" and especially in the case of the funerals, it does seem like a normal everyday event (Miller 2002). The normality in The Virgin Suicides and the calm, unimpressed tone of the narration help make the novel even more uncanny. Suicide, all of a sudden, becomes the most normal thing on the planet and something you can actually write about in a humorous way. The humor hides the ugliness of what is going on; essentially the truth. This goes back to the idea of the suburbs as a place where the ugliness of the world is hidden away. Furthermore, you are once again in this space between familiar and unfamiliar only with the addition of funny versus scary. This covering up of the harsh realities is exactly what Eugenides is trying to destroy.

The Virgin Suicides is more than anything "a novel of shared experience" (Complete Review). Not only is it the shared experience of the boys, but also the shared experience of many Americans from the 1950s and up 
until the present day. Eugenides feels that "the main purpose of literature, as it always has been, is to map human consciousness at a certain time, remembering your thoughts ... That is what novels are: a mental picture of a certain era" (Moorhem). In the case of The Virgin Suicides it is partly a mental picture of an era that has disappeared, but nevertheless an era that people desperately cling on to. The years following World War II were instrumental in shaping the America and the American way of life known to virtually everyone today. The suburban sprawl and the idea of owning your own house outside of the city appealed to the masses then and now.

The novel is thus a series of snapshots of a society-romanticized as it may be-known to most Americans. The narrative voice in The Virgin Suicides is especially interesting since Eugenides uses a collective "we" narrator and suggests a collective "we" memory of the period. About the idea of "impossible narrative voices," Eugenides says:

I seem drawn to impossible narrative voices for some reason. I think it's related to religious literature in a way. I think with the Bible and certain religious texts, this voice sort of speaks to you. You don't know where it's coming from and yet it's mesmerizing and is full of (supposed) wisdom and you have to listen to it. I like books where the narrative voice is in some way originless and you don't know exactly where it's coming from. That seems to me something that books can do that nothing else can do. And that is in a way the condition of literature as opposed to journalism, that kind of voice issuing from mystery. (Miller 2002)

The "we" narrator adds a distinct quality particularly because, since we know the voice comes from the boys, it is more or less society commenting on itself. The boys represent this collective memory of the period and suburbia.

Some of the boys see Lux as a force of nature (Eugenides 150). Indeed, it is very fitting that Lux is Latin for "light." The boys see the girls as the sun of their existence - their lives revolve around them. It shines so brightly that they cannot see the girls' flaws or differences. They fall in love with the ideal of the girls - or girl as the boys cannot tell the sisters apart. About Sofia Coppola's movie adaptation, Stephanie Zacharek states: “"The Virgin Suicides' isn't simply about the way men can fall hopelessly in love with ideals; it's about how they can be ultimately undone by them ... [Coppola] re-creates their vision for us in all its beauty, but she also suggest the holes in it - the dark spots that dance in front of you when you've been stupid enough to state directly at the sun" (Zacharek). In the novel and the movie, 
the girls become the "blinding light of love" that the robins bring in Sandy's dream. After all the suicides, the sick tree in front of the Lisbon house is cut down, and the boys "could feel how blinding the outside was becoming, our entire neighborhood like an overexposed photograph" (Eugenides 243).

The boys have to realize that "[the girls] became too powerful to live among us, too self-concerned, too visionary, too blind" (248). Again, we see how the boys and the girls mirror each other. The boys have become almost exactly what they deem the girls to be: self-concerned and blind. The light coming from behind the sick tree has been there all the time blinding the boys into an impossible dream that now they cannot escape from. But it also seems they have, perhaps, been blinded into realization: "For the first time ever, we noticed a similarity between Mrs. Lisbon's face and the faces of her daughters, but that may have been due to the black veil some people recall her as wearing. We ourselves don't remember a veil and think that detail only an elaboration of romantic memory" (240). Here, the irony is that the veil over Mrs. Lisbon's face has been the veil over the faces of the boys. They held on to the dream looking through those (veiled) windows. The death of the girls and the removal of the veil do not help matters, as the boys hold on the impossible dream - their "romantic memory." But, the boys are not alone. Again, the "we" narrator is important because the boys symbolize the common way of looking at the suburban ideal" - as a romantic ideal or, as it has become, a memory.

The perception of suburbia as the place where all the evils of the big city are nonexistent is gone. Suicides used to be a phenomenon related to the cities which is made clear when we are told that "the city newspapers had neglected to report on Cecilia's suicide because of its sheer prosaicness" (93). The reality of the novel is that "the Lisbon girls made suicide familiar" (244). Evidently, we are back to Freud and the uncanny, but with the difference that now the unfamiliar is familiar. The suicides and the reason for them remain a mystery even after the blinding light of realization shines on the boys. The boys hold on to the fantasy of the girls and keep going back to the case instead of moving on with their lives - moving on toward death. Freud writes that "the double was originally an ... "energetic denial of the power of death .... From having been an assurance of immortality, [the double] becomes the uncanny harbinger of death" (Freud 235). Furthermore, "this invention of doubling as a preservation against extinction has its counterpart in the language of dreams ..." (235). Therefore, it can be argued that the boys live vicariously through the girls or, rather, the 
dream and memory of the girls which makes them "happier with dreams than wives" thus trying to live forever (Eugenides 169).

The conclusion the boys come to is that "something sick in the heart of the country had infected the girls," and that Cecilia's first attempt at suicide had spread the poison in the air $(231,234)$. Poison and sickness are important elements in The Virgin Suicides. The elm tree in front of the Lisbon house is sick, and, seemingly, the entire street or neighborhood is infected. The sickness and the disease can very well be something repressed by all the characters and perhaps by the entire country. Freud states that repression is very important in connection with the uncanny: "this uncanny is in reality nothing new or alien, but something which is familiar and old-established in the mind which has become alienated from it only through the process of repression" (Freud 241). This goes back to the idea of the uncanny being something that ought to have remained secret and hidden but has come to light. Moreover, Tatar notes that in the case of the uncanny, we are dealing with something that "...possesses a secret once familiar but made alien by the process of forgetting" (Tatar 176). Tatar claims: "Once the token of repression is lifted from an uncanny event, what was formerly unheimlich becomes heimlich: the once hostile world becomes habitable again" (182). Yet, in the world of The Virgin Suicides the feeling of something "unheimlich" remains with the audience.

To the reader this confrontation with the world of surfaces creates a feeling that can be defined as uncanny. After all, we seem to know this world presented to us, yet there is something going on that we cannot understand or perhaps even point out. Along with the characters, we are placed in a space between the familiar and unfamiliar, a space tainted with strangeness. As we look at this world it becomes obvious that it has a double effect and functions both as a window and as a mirror: a window into another world, but at the same time, a world mirroring the one from which we observe. It becomes a mental picture of an era that is both a romantic memory and something people still strive for.

Many artists have depicted the horrors and dark underbelly of suburbia both in movies and literature. Jeffrey Eugenides does so by masterfully juxtaposing humor and horror, thus creating a novel that can be read in relation to Freud's theories of the uncanny. In this uncanny world of surfaces and images, the characters have been blinded into a life of pretending to live the ideal American way. Yet, in the end, all they see and seem is, indeed, just a dream within a dream. 


\section{Works Cited}

Cixous, Hélène. "Fiction and Its Phantoms: A Reading of Freud's Das Unheimliche (The 'uncanny')." New Literary History, Vol. 7, No. 3 (Spring 1976), 525-48.

Coppola, Sofia, dir. The Virgin Suicides. Paramount. 1999.

Duncan, Russell and Joseph Goddard. Contemporary America. New York: Palgrave Macmillian, 2003.

Eugenides, Jeffrey. The Virgin Suicides. (1993). London: Bloomsbury Publishing, 2002.

Fishman, Robert. Bourgeois Utopias: The Rise and Fall of Suburbia. New York: Basic Books Inc., 1987.

Freud, Sigmund. The Standard Edition of The Complete Psychological Works of Sigmund Freud, Vol. XVII. (1955). Translated and edited by James Strachey. London: The Hogarth Press Ltd., 1981.

Lynch, David, dir. Blue Velvet. De Laurentiis Entertainment Group (1986).

Martinson, Tom. American Dreamscape: The Pursuit of Happiness in Postwar Suburbia. New York: Carroll \& Graf Publishers, Inc., 2000.

Mendes, Sam, dir. American Beauty. DreamWorks. (1999).

Miller, Laura J. "Family Togetherness and the Suburban Ideal." Sociological Forum, Vol. 10, No. 3 (Sep., 1995), 393-418.

Poe, Edgar Allan. The Great Tales and Poems of Edgar Allan Poe (1940). New York: Pocket Books, Inc., 1941.

Silverstone, Roger, ed. Visions of Suburbia. London: Routledge, 1997.

Tatar, Maria M. "The Houses of Fiction: Toward a Definition of the Uncanny." Comparative Literature, Vol. 33, No. 2 (Spring, 1981), 167-82.

\section{Websites}

Complete Review. "The Virgin Suicides by Jeffrey Eugenides." http://www.complete-review.com/reviews/popus/eugenj2.htm

Miller, Laura. "Sex, Fate and Zeus and Hera's Kinkiest Argument." http://archive. salon. com/books/int/2002/10/08/eugenides/index.html (Miller)

Moorhem, Bram van. "3am Interview. The Novel As a Mental Picture of Its Era." http:// www.3ammagazine.com/litarchives/2003/sep/interview_jeffrey_eugenides. hıtril (Moorhem)

Zacharek, Stephanie. "The Virgin Suicides." http://dir.salon.com/ent/movies /review/ 2000/04/21/suicides/index.html (Zacharek) 